\title{
Article \\ Organo-Mineral Interactions Involved in Herbicide Sorption on Soil Amended with Peats of Different Maturity Degree
}

\author{
José Dorado $^{1, * \mathbb{C}}$ and Gonzalo Almendros ${ }^{2}$ \\ 1 Instituto de Ciencias Agrarias (CSIC), Serrano 115 B, E-28006 Madrid, Spain \\ 2 Museo Nacional de Ciencias Naturales (CSIC), Serrano 115 B, E-28006 Madrid, Spain; humus@mncn.csic.es \\ * Correspondence: jose.dorado@csic.es
}

check for updates

Citation: Dorado, J.; Almendros, G. Organo-Mineral Interactions Involved in Herbicide Sorption on Soil Amended with Peats of Different Maturity Degree. Agronomy 2021, 11, 869. https://doi.org/10.3390/ agronomy11050869

Academic Editor: Maria Roulia

Received: 9 April 2021

Accepted: 24 April 2021

Published: 28 April 2021

Publisher's Note: MDPI stays neutral with regard to jurisdictional claims in published maps and institutional affiliations.

Copyright: (c) 2021 by the authors. Licensee MDPI, Basel, Switzerland. This article is an open access article distributed under the terms and conditions of the Creative Commons Attribution (CC BY) license (https:// creativecommons.org/licenses/by/ $4.0 /)$.

\begin{abstract}
The sorption of three herbicides (alachlor, atrazine and linuron) on samples from six peats of progressive degree of maturity (fibric, hemic or sapric types) and soil samples (dryland agricultural Calcic Luvisol amended with the peats) was determined. The extent of the sorption was examined in terms of peat maturity (up to 220 analytical descriptors of the peat material). In most cases, a sorption enhancement effect was observed in the peat-soil system compared with the sum of the sorption in peat and soil alone, i.e., a positive interaction leading to an increase in soil matrix reactive sites. The analytical characteristics of humic and bitumen peat subfractions were useful in forecasting sorption performance. This was the case for high molecular weight hydrophobic fractions, the extent of the alkyl domain in humic substances and oxygen-containing groups. Correspondence analysis illustrated how different characteristics of the peats played a distinct role in sorption in the herbicide-peat system or in the soil-peat-herbicide system. In the former system, there was a relevant bearing of parameters indicating low peat maturity, whereas in the second the sorption was mainly explained by peat colloidal properties, including the concentration and base saturation of oxygen-containing functional groups.
\end{abstract}

Keywords: humic substances; pesticide sorption; alachlor; atrazine; linuron; soil amendment; Calcic Luvisol; Histosol; multivariate analysis

\section{Introduction}

The role of soil organic matter in enhancing the sorption of a wide variety of low molecular weight organic compounds incorporated into agricultural soils as pesticides has been the subject of several studies [1,2]. In fact, the outstanding effect of soil organic matter on the agronomic quality of the soil is not only indirect, through its function of improving soil hydrophysical properties, as a reserve, a carrier of nutrients in continuous release forms, or a regulating agent in the mobility of pesticides or pollutants [3], but also through a recognized direct effect on the stimulation of plant growth [4].

In particular, the residual effect of pesticides applied to the soil can affect crop growth in the medium term, as has recently been reviewed in the case of atrazine and trifluralin residues [5]. Although there are many factors involved in the sorption and desorption of pesticides in the soil, numerous studies indicate that the proportion and nature of the soil organic matter are the factors that explain to a greater extent its persistence and activity in agricultural soils [6,7]. Regardless of this, the nature of the interactions involved in the sorption of pesticides on individual soil constituents is known only to a very limited extent, although it seems clear that the retention process is the result of the combined effect of a number of physical and chemical processes ranging from electrostatic interactions to covalent bonding [8].

The mechanisms of sorption of pesticides by organic matter include $\mathrm{H}$-bonding, proton transfer, charge transfer, and van der Waals forces [9]. Consequently, humic-type organic matter, of a highly variable nature depending on its origin, displays sorption properties highly dependent on the reactivity of its surfaces, but also on diffusion processes, i.e., dependent 
on the microporosity of the sorbate [10]. In this regard, not only the total content of soil organic matter, but also its chemical structure, systematically has a significant effect on its environmental properties. For instance, several studies have established that the molecular composition of the organic matter, particularly its oxygen-containing functional groups, can significantly influence the bioavailability, mobility, and migration of atrazine in different land uses [11,12]. However, there are still few studies on the importance of the composition and structure of soil organic matter in its role in the retention of pesticides [13-15] and, in particular, on the extent to which the organo-mineral interactions can regulate the sorptive behavior of organic matter in the function of different types of soils [16].

The degree of maturity of the soil organic matter is also of great importance in the functioning of the soil biogeochemical cycle, and there are numerous recent studies suggesting that the different molecular composition of humus is related to the biodegradability of organic matter and consequently in the soil organic carbon storage capacity of soils [17-19]. In particular, the aromaticity of humic substances or, conversely the hydrophobicity/aromaticity ratio, seems to be a determining factor and explains much of the variability of atrazine absorption [20-22]. Several studies have found that the application to soil of highly aromatic organic amendments (such as humus with a high degree of maturity or different forms of fossil or pyrogenic organic matter, i.e., black carbon) has an outstanding influence on atrazine sorption [23-25]. In the case of alachlor, it was found that, although tillage practices did not significantly affect its sorption into the soil, biochar (highly aromatic soil amendment) increased its sorption between $4 \times$ and $33 \times$ compared to unamended soil [26].

In addition to the obvious importance of the molecular structure of organic matter in its interactions with pesticides, there are few experimental studies that show the regulatory role of organo-mineral interactions in the absorption process, because they affect the reactivity of the functional groups or simply the accessibility of the different reactive surfaces of organic matter. It seems clear that not only the different composition of the soil organic matter, but also its state of association with the soil matrix are important in the pesticide sorption $[27,28]$. This is particularly noticeable in the case of humic substances with outstanding sorptive properties [29], where it is well known that their maturity, or degree of humification, plays a determining role in the response of the agrosystem [16,19].

For instance, in the case of atrazine, it has been shown that its fate under natural conditions, including its biodegradability [30], is highly influenced by, e.g., the formation of organometallic copper complexes [31], complexes between clays and metals and humic substances [32], formation of mobile complexes between dissolved organic carbon and atrazine [33], and formation of sodium or calcium humic acid salts with different solubility [34]. When considering the complex three-dimensional structure of the $\mathrm{C}$ backbone of soil humic substances, it is likely that most types of sorptive interactions depend on steric hindrances such are molecular encapsulation in the soil matrix in a system in which hydrophobic bonding, diffusion processes, and solid solution processes also play a relevant role in regulating the bioavailability of most pesticides entering the soil $[35,36]$.

Most of the current information on pesticide sorption mechanisms has been obtained from relatively simple laboratory systems with isolated and purified humic substances (humic acids or fulvic acids) interacting with pesticide solutions. Nevertheless, comparatively little information is generally available on heterogeneous humified organic substrates such as peats, lignites, or other types of organic sediments rich in humic substances [37]. In general, the particulate organic (or organo-mineral) soil fractions could also include stable microaggregates where the retention of pesticides could depend more on steric factors and diffusion mechanisms than on the type and amounts of oxygen-containing functional groups [38,39].

As organic soils, the various types of peat have traditionally been used as horticultural substrates or as soil amendments. Despite their richness in alkali-soluble humus, most peats (mainly the so-called fibric and hemic types) are often used to improve the physical or chemical properties of the soil, and are largely composed of preserved plant tissues. Depending on the extent to which plant residues have been transformed into humic substances, different kinds of peat are considered, ranging from macroscopic moss fibers to 
amorphous lignite-like materials. This suggests that not only the total sorptive potential, but mainly the selectivity and the mechanisms involved in the retention of compounds of low molecular weight, would largely depend on the degree of decomposition of the peat.

Apart from the functional relationships involved in the behavior of peat as a sorbate, the incorporation of peat into the soil promotes the formation of newly formed aggregates with a lasting effect on its matrix physicochemical features, such as the availability of oxygen-containing functional groups and the distribution of hydrophobic surfaces. For these reasons-although such a process has not been extensively studied-it is expected that pesticide sorption patterns will change in a manner depending on organo-mineral interactions. The experimental assessment of such a process would provide useful information on the mechanisms related to the retention of pesticides in heterogeneous natural systems such as soils improved with inputs of exogenous organic matter.

In the present study, the sorption of three herbicides in a Calcic Luvisol is examined and their sorption is also compared in samples from six types of peat with very different maturity or degree of decomposition. In a further experiment, Luvisol samples are treated with the peats and, after an incubation period of 2 weeks, the herbicide sorption in the resulting mixture is also determined and the differences in terms of the interactions between peat and soil are discussed.

\section{Materials and Methods}

\subsection{Chemicals}

Standards of analytical grade of 3 herbicides were used for the sorption experiments: alachlor (2-chloro-N-(2,6-diethylphenyl)-N-(methoxymethyl)acetamide) (Chem Service Inc., West Chester, PA, USA), atrazine (6-chloro-N-ethyl-N'-(1-methylethyl)- 1,3,5triazine-2,4-diamine) (Dr. Ehrenstorfer GmbH, Augsburg, Germany) and linuron (N(3,4-dichlorophenyl)- $\mathrm{N}^{\prime}$-methoxy- $\mathrm{N}^{\prime}$-methylurea) (Chem Service Inc.). Water solutions of $25 \mathrm{mg} \mathrm{L}^{-1}$ of atrazine, and of $50 \mathrm{mg} \mathrm{L}^{-1}$ of alachlor and linuron were prepared for the routine measurement of herbicide concentration. In the case of atrazine (comparatively low solubility in water) a previous solution was prepared in $2 \mathrm{~mL}$ of acetonitrile and the final volume was adjusted with distilled water to $1 \mathrm{~L}$.

\subsection{Soil, Peat and Soil-Peat Systems}

The soil material used in the experiments was collected from a Calcic Luvisol in the CSIC experimental farm "La Higueruela" (Toledo, Central Spain) with a pH of 4.5, oxidizable $C$ content of $5 \mathrm{~g} \mathrm{~kg}^{-1}$, total cation exchange capacity of $12.5 \mathrm{cmolc} \mathrm{kg}^{-1}$, sand $780 \mathrm{~g} \mathrm{~kg}^{-1}$ and clay $140 \mathrm{~g} \mathrm{~kg}^{-1}$. Topsoil samples were collected with a spade $(0-20 \mathrm{~cm}$ depth), roots and gravel were removed in the field, and the soil material was air-dried in the laboratory and homogenized to $<2 \mathrm{~mm}$ (fine earth).

This soil was chosen because it is considered highly representative of the semi-arid cultivated soils of central Spain. In addition, it is a reference soil from an Experimental Station where long-term experiments are carried out, and there are historical data on the evolution of soil properties and their response to different types of use. Moreover, data on its mineralogical composition, physical properties, and crop production are available. The organic carbon content of this soil is very low, which makes it especially suitable for experiments based on the effect of the application of external sources of organic matter. The molecular composition of its organic matter and the effects of different tillage practices have also been the subject of previous investigations [40].

Most of the peat samples used were collected from different Spanish basements with a wide range of variability in terms of maturity: Daimiel (Ciudad Real), Mazagón (Huelva), Padul (Granada), Torreblanca (Castellón de la Plana) and Vivero (Lugo). In addition, a Sphagnum peat (rare in Spain) corresponding to a commercial German peat (Neuhaus substrate) was purchased [41-45]. The peat samples were dried at room temperature, homogenized by grinding with a knife mill to $100 \mu \mathrm{m}$, and the hygroscopic moisture was determined from oven-dried samples at $105^{\circ} \mathrm{C}$, to make corrections in further calculations. 
To prepare the soil amended with peat with optimum incorporation of the organic and mineral matter, $50 \mathrm{~mL} \mathrm{H} \mathrm{H}_{2} \mathrm{O}$ was added to a mixture of $200 \mathrm{~g}$ of soil-peat 1:1 (wt:wt), mechanically homogenized with a rotary stirrer in a $500 \mathrm{~mL}$ polypropylene beaker, and allowed to dry on a Petri dish at room temperature for two weeks, while manually homogenizing with a spatula in the advanced desiccation stages to avoid compaction and favor the formation of aggregates. The final mixture of soil and peat was sieved to $2 \mathrm{~mm}$ and stored for sorption measurements. Control samples of peats and soil were treated in parallel.

\subsection{Analytical Characterization of Peat Samples}

The fiber content (particles $>0.1 \mathrm{~mm}$ ) was obtained after suspending the peat in a solution of $50 \mathrm{~g} \mathrm{~L}^{-1}$ sodium hexametaphosphate. The porosity and the bulk density (dry or wet volume basis) were calculated from undisturbed peat cores (154 mL cylinders) by considering either the total volume (wet volume) and the dry volume. The latter was estimated by difference after filling with fine sand the empty volume of the cylinder after peat shrinking during desiccation. The ash content was gravimetrically calculated after burning the samples in an electric furnace at $600{ }^{\circ} \mathrm{C}$. The $\mathrm{pH}$ was determined in water using a 1:2.5 wt:wt ratio. The water retention at 30,175, and $1500 \mathrm{kPa}$ was analyzed in a Richard's pressure-membrane extractor (Soilmoisture Equipment Corp., Santa Barbara, CA, USA). The organic $C$ was determined by the wet oxidation method [46]. Due to the presence of carbonates in several samples, the analysis of the exchangeable cations was carried out after extraction with $\mathrm{BaCl}_{2}$ at $\mathrm{pH}=8.1$ [47]. Peat microelements were analyzed by atomic absorption spectroscopy after $\mathrm{HCl}$ digestion of peat ashes.

Routine methods were used to extract and purify the different organic fractions $[48,49]$. The total bitumen was extracted on a Soxhlet with EtOH: $\mathrm{C}_{6} \mathrm{H}_{6}$ (1:1 by vol.) for 2 days. The alkali-soluble humic substances were isolated by successive extractions with $0.1 \mathrm{~mol} \mathrm{~L}^{-1}$ $\mathrm{Na}_{4} \mathrm{P}_{2} \mathrm{O}_{7}$ and $0.1 \mathrm{~mol} \mathrm{~L}{ }^{-1} \mathrm{NaOH}$. From the obtained extract, humic acid (HA) was separated from fulvic acid (FA) by precipitating at $\mathrm{pH} 1.5$ with $\mathrm{HCl}$. The alcohol-soluble subfraction of HA, namely hymatomelanic acid fraction was obtained from the HA in a Soxhlet with ethanol for $48 \mathrm{~h}$. The FA fraction was concentrated by adsorption on a column with activated charcoal, which was eluted with water to remove soluble salts, then recovered by elution with ammonium hydroxide and acetone [50]. Finally, the FA was purified by elution on Amberlite ${ }^{\circledR}$ IR-120 $\mathrm{H}^{+}$.

Residual plant macromolecular fractions (celluloses, hemicelluloses, lignin) were determined by standard sequential hydrolysis [51] followed by colorimetric determination of sugars [52]. Lignin (acid-insoluble residue) was calculated from the ashfree weight difference.

Some characteristics of the isolated HA and FA were studied by routine methods. The elementary composition $(\mathrm{C}, \mathrm{H}, \mathrm{N})$ was determined with a Hewlett Packard $185 \mathrm{CHN}$ analyzer; the $\mathrm{O}$ was calculated by difference (ashfree basis). The visible spectra and the optical densities of the HAs and FAs at 465 and $665 \mathrm{~nm}$ were measured from solutions of $0.136 \mathrm{mg} \mathrm{C} \mathrm{mL}^{-1}$ in $0.02 \mathrm{~mol} \mathrm{~L}^{-1} \mathrm{NaHCO}_{3}$ [53]. Additional structural information was obtained by infrared (IR) spectroscopy, the spectra being acquired between 4000 and $400 \mathrm{~cm}^{-1}$ with a Perkin-Elmer 325 instrument (Perkinelmer España SL, Tres Cantos, Madrid, Spain) using KBr wafers with 2 mg HA or FA in 200 mg KBr.

Finally, the total bitumen was divided into five sub-fractions: in a first step, the waxes (insoluble in ethanol at $0^{\circ} \mathrm{C}$ ) were separated from the resins (supernatant yellowish solution). The waxes were then chromatographically subdivided into additional subfractions by successive elution with an eluotropic series $\left(\mathrm{S}_{2} \mathrm{C}, \mathrm{CHCl}_{3}-\mathrm{CH}_{3} \mathrm{CO}_{2} \mathrm{H}\right.$ 10:1 by vol., and $\mathrm{CHCl}_{3}-\mathrm{HCO}_{2} \mathrm{H}$ 1:1 by vol.) on a silica gel column. The eluents called hydrocarbon fraction, ester fraction, and acid fraction are recovered successively [54]. The non-eluted bitumen remaining on the column was calculated by difference.

\subsection{Herbicide Sorption Measurements}

Samples of $0.3 \mathrm{~g}$ of peat or a mixture of peat and soil (containing $0.15 \mathrm{~g}$ peat and $0.15 \mathrm{~g}$ soil) were treated in triplicate with $10 \mathrm{~mL}$ of the 25 or $50 \mathrm{mg} \mathrm{L}^{-1}$ herbicide solution 
(concentration within the linear range of the sorption isotherms of the three herbicides under the conditions studied) and mechanically shaken for $24 \mathrm{~h}$ at $25^{\circ} \mathrm{C}$. The suspension was centrifuged at $48,200 \times g$ and an aliquot of ca. $3 \mathrm{~mL}$ of the supernatant solution was transferred through a $0.2 \mu \mathrm{m}$ pore size syringe tip filter to a spectrophotometer quartz cuvette to remove any turbidity.

The herbicide concentration in the supernatant solution was determined by second derivative ultraviolet spectroscopy [55] with a Shimadzu UV-240, OPI-2 spectrophotometer (Izasa Scientific, Alcobendas, Madrid, Spain) as a linear function of the intensity of the diagnostic spectral maximum selected for each herbicide: $267 \mathrm{~nm}$ for alachlor and atrazine, and 253 for linuron [16]. In the above experimental conditions, the detection threshold of the three herbicides was ca. $0.5 \mathrm{mg} \mathrm{L}^{-1}$.

\subsection{Statistical Procedures}

Univariate and multivariate data analyses were carried out with the STAT-ITCF software [56] using a data matrix with the samples corresponding to the different peats. The variables were the physico-chemical characteristics of the peats, which included the sorption values of each herbicide either in the peats or in the peat-soil mixtures. For each herbicide, simple and multiple linear regression models were calculated to identify the main physical and/or chemical features related to the sorption of the herbicide (dependent variable).

A correspondence analysis was carried out to identify the most relevant characteristics of the peat as regards to the sorption of herbicides in peat alone or in peat-soil mixtures, and to get an idea of the variable patterns involved in the sorption of the different herbicides. With this treatment, a final plot is obtained in which both the scores of samples and variables are shown in a two-dimensional scatter diagram in the space defined by factorial axes corresponding to multiple linear functions of the original descriptors of the peats.

\section{Results}

Tables 1-3 show a selection of the analytical characteristics of the peats and their organic fractions with some bearing on uni- and multivariate models to forecast herbicide sorption. The selection of the data shown in these Tables was made after an exploratory study of the groups of independent variables that showed more significant correlations with the sorption of herbicides, in an attempt to avoid discussing other unnecessary data to explain the sorption variability.

The data illustrated large diversity in peat properties with $\mathrm{C}$ concentrations ranging

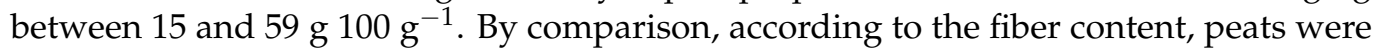
classified as fibric (Neuhaus), hemic (Daimiel and Vivero) and sapric (Mazagón, Torreblanca and Padul), the latter peat being often considered as a low-rank lignite. Mainly sapric peats showed high concentration of HAs (36 to 51 percent of their total C) with a high degree of maturity, whereas in the fibric peats, plant fragments (Sphagnum, Phragmites) were comparatively abundant.

The sorption of alachlor, linuron, and atrazine in the three different systems, i.e., (i) soil, (ii) peat, and (iii) peat in soil, is shown in Table 4. It is clear that, when referring to the weight of sorbate, the sorption of alachlor, atrazine, and linuron was about 14, 24, and 11 times higher, respectively, in Neuhaus and Vivero peats than the sorption in soil alone. Linuron sorption in the soil used for the experiment was found to be significantly higher than alachlor sorption, and the latter was higher than that of atrazine.

Similar behavior was also found in peat and in peat-soil systems. Regarding the sorption in terms of the type of peat, significant differences were observed between samples, the sorption values following the order Neuhaus $>$ Vivero $>$ Torreblanca, with the sorptive capacity of these peats being around two-fold greater than in peats from Padul, Mazagón, and Daimiel basements.

Table 4 also illustrates the sorptive behavior in both peat and soil-peat systems, showing the effect of soil interaction (sorption enhancement). Because the values are expressed on a sample weight basis, if no organo-mineral interaction occurs in the soil-peat system as in the case of a physical mixture, the results for the peat in the soil might be equal 
to those obtained by the sum of the sorption in peat alone and soil alone. Nevertheless, these sorption values increased or decreased to a significant extent.

Values less than 100 (expressed as the percentage ratio between the sorption in peattreated soil and the halfsum of sorptions in peat alone and soil alone) would indicate a negative effect that could be reflecting the mutual blocking of active bonding sites of the organic and the mineral matrix which hinders herbicide retention. Conversely, a positive effect (values greater than 100), which was found in most of the cases (Table 4), could be attributed with large probability to new active sites in the soil mineral matrix.

Table 1. Main physical and chemical characteristics of peats.

\begin{tabular}{|c|c|c|c|c|c|c|}
\hline & Daimiel Peat & Mazagón Peat & Neuhaus Peat & Padul Peat & Torreblanca Peat & Vivero Peat \\
\hline Fibers $(0.5-1.0 \mathrm{~mm})\left({\left.\mathrm{g} 100 \mathrm{~g}^{-1}\right)}^{2}\right.$ & 0.5 & 1.3 & 6.9 & 0.4 & 2.3 & 4.6 \\
\hline Fibers $(0.25-0.50 \mathrm{~mm})\left(\mathrm{g} \mathrm{t} 00 \mathrm{~g}^{-1}\right)$ & 1.0 & 1.6 & 6.6 & 0.4 & 4.6 & 5.6 \\
\hline Total fibers $\left({\left.\mathrm{g} 100 \mathrm{~g}^{-1}\right)}^{2}\right.$ & 55.6 & 7.0 & 93.8 & 1.8 & 15.5 & 52.5 \\
\hline Peat type & Hemic & Sapric & Fibric & Sapric & Sapric & Hemic \\
\hline Porosity $\left(\mathrm{mL} \mathrm{L}^{-1}\right)$ & 962 & 827 & 881 & 909 & 923 & 900 \\
\hline Water holding capacity $\left(\mathrm{g} 100 \mathrm{~g}^{-1}\right)$ & 839 & 124 & 1297 & 865 & 914 & 588 \\
\hline Wet bulk density $\left(\mathrm{g} \mathrm{mL}^{-1}\right)$ & 0.09 & 0.32 & 0.05 & 0.18 & 0.12 & 0.13 \\
\hline Dry bulk density $\left(\mathrm{g} \mathrm{mL}^{-1}\right)$ & 0.71 & 0.43 & 0.13 & 0.38 & 0.44 & 0.36 \\
\hline Wet-to-dry bulk density ratio & 0.12 & 0.74 & 0.69 & 0.47 & 0.27 & 0.37 \\
\hline Particle density $\left(\mathrm{g} \mathrm{mL}^{-1}\right)$ & 2.4 & 1.8 & 0.4 & 2.0 & 1.6 & 2.2 \\
\hline $\mathrm{pH}$ & 7.4 & 2.4 & 3.5 & 5.5 & 6.4 & 3.6 \\
\hline Oxidizable C (g $\left.100 \mathrm{~g}^{-1}\right)$ & 15.0 & 20.7 & 58.6 & 47.2 & 36.7 & 57.5 \\
\hline $\mathrm{C} / \mathrm{N}$ ratio & 24.3 & 19.5 & 78.1 & 27.3 & 20.4 & 33.6 \\
\hline $\begin{array}{l}\text { Total exchange capacity, } \\
\mathrm{T}\left(\mathrm{cmol}_{\mathrm{c}} \mathrm{kg}^{-1}\right)\end{array}$ & 109.0 & 55.5 & 63.9 & 61.7 & 143.4 & 131.6 \\
\hline $\begin{array}{c}\text { Exchangeable bases, } \\
\mathrm{S}\left(\mathrm{cmol}_{\mathrm{c}} \mathrm{kg}^{-1}\right)\end{array}$ & 89.2 & 12.8 & 12.3 & 27.4 & 124.5 & 7.7 \\
\hline Base saturation $(V=100 \mathrm{~S} / \mathrm{T})$ & 81.8 & 23.0 & 19.2 & 44.5 & 86.9 & 5.8 \\
\hline 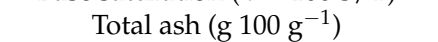 & 68.3 & 63.2 & 1.5 & 16.7 & 28.1 & 3.4 \\
\hline $\mathrm{Cu}\left(\mathrm{mg} \mathrm{kg}^{-1} \mathrm{ash}\right)$ & 0.04 & 0.02 & 0.30 & 0.05 & 0.12 & 0.21 \\
\hline
\end{tabular}

Table 2. Major organic fractions in peats.

\begin{tabular}{|c|c|c|c|c|c|c|}
\hline & Daimiel Peat & Mazagón Peat & Neuhaus Peat & Padul Peat & Torreblanca Peat & Vivero Peat \\
\hline \multirow[t]{2}{*}{ Total humic extract } & $8.8^{a}$ & 14.6 & 19.2 & 26.7 & 20.0 & 26.2 \\
\hline & $58.9^{b}$ & 70.7 & 32.8 & 53.6 & 54.6 & 45.6 \\
\hline \multirow[t]{2}{*}{ Humic acid } & $6.8^{\mathrm{a}}$ & 10.6 & 12.3 & 17.2 & 15.2 & 15.0 \\
\hline & $45.2^{b}$ & 51.0 & 20.9 & 36.4 & 41.4 & 26.0 \\
\hline Hymatomelanic acid & $2.0^{\mathrm{c}}$ & 9.3 & 15.7 & 13.5 & 0.1 & 7.9 \\
\hline \multirow[t]{2}{*}{ Fulvic acid } & $2.1^{\mathrm{a}}$ & 4.1 & 7.0 & 9.5 & 4.8 & 11.3 \\
\hline & $13.8^{\mathrm{b}}$ & 19.6 & 11.9 & 22.5 & 13.1 & 19.6 \\
\hline \multirow[t]{2}{*}{ Total bitumen } & $0.9^{\mathrm{a}}$ & 3.3 & 7.5 & 1.5 & 2.0 & 4.7 \\
\hline & $6.0^{b}$ & 15.9 & 12.8 & 3.2 & 5.5 & 8.3 \\
\hline \multirow[t]{2}{*}{ Total wax } & $0.6^{\mathrm{a}}$ & 1.9 & 2.5 & 1.0 & 1.0 & 1.7 \\
\hline & $69.9^{d}$ & 58.2 & 33.2 & 68.7 & 49.2 & 36.2 \\
\hline \multirow[t]{2}{*}{ Hydrocarbon } & $0.2^{\mathrm{a}}$ & 0.4 & 0.9 & 0.4 & 0.3 & 0.6 \\
\hline & $24.1^{\mathrm{e}}$ & 13.5 & 12.4 & 24.0 & 13.3 & 35.3 \\
\hline \multirow[t]{2}{*}{ Ester } & $0.3^{\mathrm{a}}$ & 1.1 & 0.7 & 0.4 & 0.5 & 0.9 \\
\hline & $31.3^{\mathrm{e}}$ & 34.8 & 9.4 & 29.2 & 24.1 & 52.9 \\
\hline \multirow[t]{2}{*}{ Acid } & $0.1^{\mathrm{a}}$ & 0.2 & 0.2 & 0.1 & 0.1 & 0.2 \\
\hline & $8.4^{\mathrm{e}}$ & 5.8 & 3.2 & 6.0 & 3.1 & 11.8 \\
\hline \multirow[t]{2}{*}{ Total resin } & $0.3^{\mathrm{a}}$ & 1.4 & 5.0 & 0.5 & 1.0 & 3.0 \\
\hline & $30.1^{\mathrm{c}}$ & 41.9 & 66.8 & 31.3 & 50.8 & 63.8 \\
\hline \multirow[t]{2}{*}{ Cellulose } & $0.5^{\mathrm{a}}$ & 1.2 & 10.0 & 0.9 & 0.6 & 5.3 \\
\hline & $3.0^{b}$ & 5.7 & 17.0 & 2.0 & 1.7 & 9.2 \\
\hline \multirow[t]{2}{*}{ Hemicellulose } & $0.5^{\mathrm{a}}$ & 0.4 & 4.3 & 0.7 & 1.8 & 3.0 \\
\hline & $3.5^{b}$ & 1.8 & 7.3 & 1.4 & 4.9 & 5.3 \\
\hline \multirow[t]{2}{*}{ Lignin } & $3.8^{\mathrm{a}}$ & 3.3 & 16.6 & 17.0 & 9.1 & 31.3 \\
\hline & $25.7^{b}$ & 15.9 & 28.4 & 32.0 & 24.7 & 54.4 \\
\hline
\end{tabular}

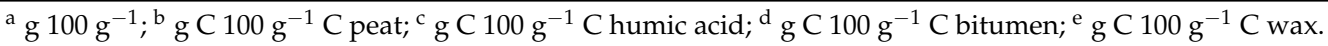


The interaction patterns observed in this work-with the least decomposed peats showing a tendency to greater sorption after interaction with the soil-also appear to depend on the herbicide. For instance, the decrease in sorption after interaction with the soil was more frequent with atrazine (the heterocyclic ring of which being considered to confer it with a high possibility of polar and charge-transfer interactions).

Simple (Table 5 and Figure 1) and multiple (Table 6) regression models were calculated to shed any light on the properties of peat that would act as surrogate indicators-or be causally related - to the ability of organic matter to retain herbicide molecules. For these correlation studies, a supervised prior selection of the variables was carried out to verify the normal distribution of the data. Additional visual inspection of the resulting correlation plots was carried out to rule out spurious significant correlations due to the presence of outliers. In the multiple regression analysis, the standard error of the estimate was inspected, which shows the standard deviation of the residuals.
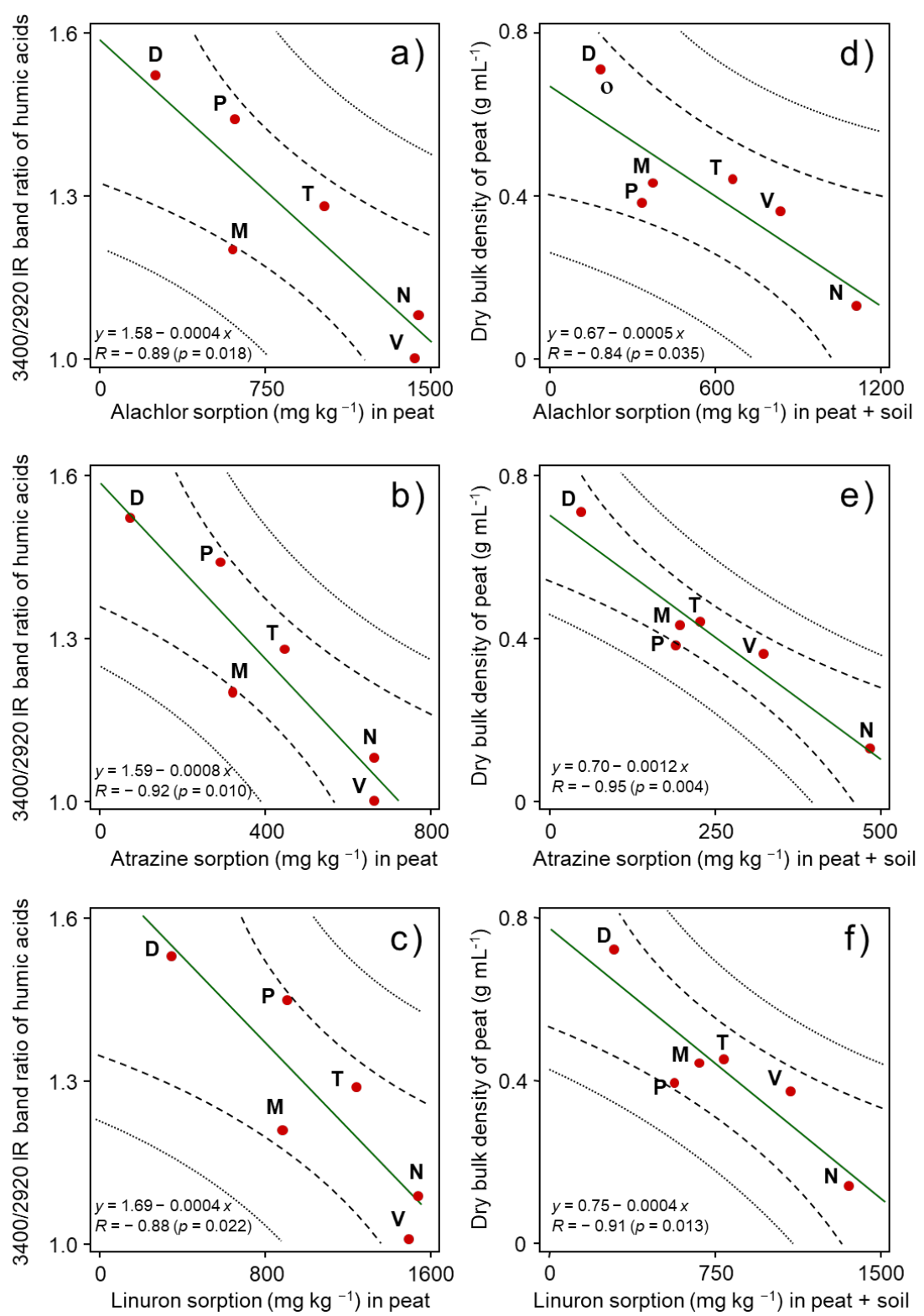

Figure 1. Relations between herbicide sorption in peat and the $3400 / 2920 \mathrm{~cm}^{-1}$ intensity ratio in the IR spectra of humic acids $(\mathbf{a}-\mathbf{c})$, and between the herbicide sorption in peat-soil system and the dry bulk density of peat (d-f). $\mathrm{D}=$ Daimiel; $\mathrm{M}=$ Mazagón; $\mathrm{N}=$ Neuhaus; $\mathrm{P}=$ Padul; $\mathrm{T}=$ Torreblanca; $\mathrm{V}=$ Vivero. Dashed and dotted lines indicate $95 \%$ confidence and prediction limits, respectively. 
Table 3. Chemical and spectroscopic characteristics of peats and their humic acid and fulvic acid fractions.

\begin{tabular}{|c|c|c|c|c|c|c|}
\hline & Daimiel Peat & Mazagón Peat & Neuhaus Peat & Padul Peat & Torreblanca Peat & Vivero Pea \\
\hline \multicolumn{7}{|l|}{ Total peat } \\
\hline $3400 / 2920$ intensity ratio in IR spectra & 0.1 & 2.9 & 0.4 & 1.0 & 0.6 & 0.5 \\
\hline \multicolumn{7}{|l|}{ Humic acid } \\
\hline $3400 / 2920$ intensity ratio in IR spectra & 0.9 & 0.9 & 1.9 & 0.8 & 0.9 & 1.4 \\
\hline $1720 / 2920$ intensity ratio in IR spectra & 0.4 & 0.3 & 0.4 & 0.4 & 0.4 & 0.5 \\
\hline \multicolumn{7}{|l|}{ Fulvic acid } \\
\hline $\mathrm{C}$ (elementary composition) ( $\left.\mathrm{g} 100 \mathrm{~g}^{-1}\right)$ & 37.2 & 43.3 & 23.4 & 43.3 & 37.9 & 30.6 \\
\hline $\mathrm{H} / \mathrm{C}$ atomic ratio & 0.06 & 0.09 & 0.13 & 0.11 & 0.13 & 0.13 \\
\hline $3400 / 2920$ intensity ratio in IR spectra & 0.8 & 0.9 & 1.2 & 1.2 & 0.9 & 1.9 \\
\hline $1720 / 2920$ intensity ratio in IR spectra & 0.3 & 0.5 & 0.4 & 0.4 & 0.4 & 0.4 \\
\hline
\end{tabular}

Table 4. Sorption of alachlor, linuron $\left(50 \mathrm{mg} \mathrm{L}^{-1}\right)$, and atrazine $\left(25 \mathrm{mg} \mathrm{L}^{-1}\right)$ in soil, peat, and peat-treated soil samples, and sorption enhancement after peat interaction with soil.

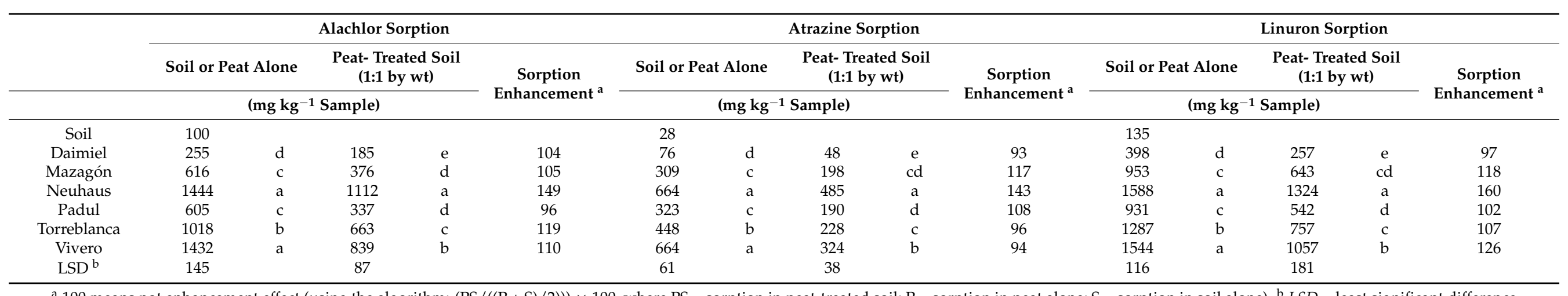

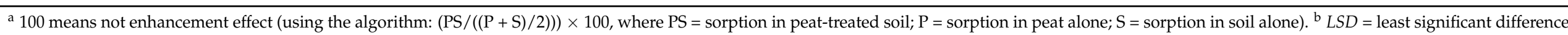
at $p=0.05$. Means in a column followed by the same letter are not significantly different $(p<0.05)$. 


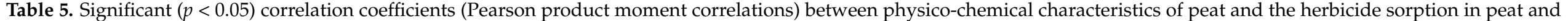
peat-treated soil ${ }^{\mathrm{a}}$.

\begin{tabular}{|c|c|c|c|c|c|c|}
\hline & \multicolumn{2}{|c|}{ Alachlor Sorption } & \multicolumn{2}{|c|}{ Atrazine Sorption } & \multicolumn{2}{|c|}{ Linuron Sorption } \\
\hline & Peat Alone & Peat- Treated Soil & Peat Alone & Peat- Treated Soil & Peat Alone & Peat- Treated Soil \\
\hline \multicolumn{7}{|l|}{ Peat properties } \\
\hline Fibers $(0.5-1.0 \mathrm{~mm})$ & 0.86 & $0.93 *$ & ns & ns & ns & 0.91 \\
\hline Fibers $(0.25-0.50 \mathrm{~mm})$ & 0.88 & 0.92 & ns & ns & ns & 0.83 \\
\hline Dry bulk density & -0.81 & -0.85 & -0.86 & $-0.95 *$ & -0.87 & -0.91 \\
\hline Actual density & $-0.93 *$ & $-0.95 *$ & $-0.92 *$ & $-0.96^{*}$ & -0.87 & $-0.97^{*}$ \\
\hline Total ash & -0.85 & ns & -0.87 & ns & -0.85 & ns \\
\hline $\mathrm{Cu}$ in ash & 0.86 & $0.92 *$ & ns & ns & ns & 0.86 \\
\hline Oxidizable C & 0.86 & 0.81 & 0.89 & 0.84 & 0.85 & 0.83 \\
\hline Total bitumen in peat $(\%)$ & 0.81 & 0.83 & 0.81 & 0.90 & ns & 0.89 \\
\hline Wax C in total bitumen (\%) & $-0.92 *$ & $-0.94 *$ & -0.87 & -0.87 & -0.85 & -0.91 \\
\hline Total hydrocarbon in peat (\%) & ns & ns & ns & 0.89 & ns & 0.85 \\
\hline Wax acid C in total wax (\%) & -0.88 & ns & -0.88 & ns & $-0.93 *$ & ns \\
\hline Total resin in peat $(\%)$ & ns & 0.87 & ns & 0.90 & ns & 0.90 \\
\hline Resin C in total bitumen (\%) & $0.92 *$ & 0.94 * & 0.87 & 0.87 & 0.85 & 0.91 \\
\hline Hemicellulose in peat $(\%)$ & 0.87 & $0.93 *$ & 0.81 & 0.86 & ns & 0.87 \\
\hline $3400 / 2920$ intensity ratio in IR spectra & ns & ns & -0.82 & $-0.93 *$ & ns & -0.90 \\
\hline \multicolumn{7}{|l|}{ Humic acid properties } \\
\hline 3400/2920 IR intensity ratio & -0.89 & -0.81 & -0.91 & -0.81 & -0.88 & -0.83 \\
\hline 1720/2920 IR intensity ratio & -0.88 & -0.82 & $-0.92 *$ & -0.88 & -0.90 & -0.91 \\
\hline $\mathrm{H} / \mathrm{C}$ atomic ratio & 0.82 & ns & 0.85 & ns & 0.89 & ns \\
\hline $3400 / 2920$ IR intensity ratio & -0.85 & ns & -0.89 & ns & $-0.93 *$ & -0.81 \\
\hline
\end{tabular}

${ }^{a}$ Calculated by subtracting the sorption in soil, independently measured at the same concentration and sample-to-solution ratio. ${ }^{*} p<0.01$; ns $=$ non-significant $(p>0.05)$. 


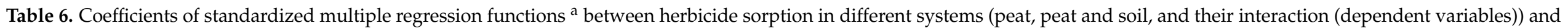
physico-chemical characteristics of peats.

\begin{tabular}{|c|c|c|c|c|c|c|c|c|c|}
\hline & \multicolumn{3}{|c|}{ Alachlor Sorption } & \multicolumn{3}{|c|}{ Atrazine Sorption } & \multicolumn{3}{|c|}{ Linuron Sorption } \\
\hline & Peat Alone & $\begin{array}{c}\text { Peat- Treated } \\
\text { Soil }\end{array}$ & $\begin{array}{c}\text { Sorption } \\
\text { Enhancement }\end{array}$ & Peat Alone & $\begin{array}{c}\text { Peat- Treated } \\
\text { Soil }\end{array}$ & $\begin{array}{c}\text { Sorption } \\
\text { Enhancement }\end{array}$ & Peat Alone & $\begin{array}{l}\text { Peat- Treated } \\
\text { Soil }\end{array}$ & $\begin{array}{c}\text { Sorption } \\
\text { Enhancement }\end{array}$ \\
\hline \multicolumn{10}{|l|}{ Peat properties } \\
\hline Fibers $(0.25-0.50 \mathrm{~mm})$ & ns & ns & 0.52 & ns & ns & ns & ns & ns & ns \\
\hline Oxidizable C & 0.19 & ns & ns & ns & ns & ns & 0.23 & ns & ns \\
\hline Percentage of total humic extract $C$ & ns & -0.16 & ns & ns & ns & ns & ns & ns & ns \\
\hline Percentage of humic acid $C$ in peat & ns & ns & ns & -0.30 & -0.36 & ns & ns & -0.11 & ns \\
\hline Percentage of total bitumen in peat & ns & ns & 0.28 & 0.17 & ns & ns & ns & ns & ns \\
\hline Percentage of wax $C$ in total bitumen & -0.67 & ns & ns & ns & ns & ns & ns & ns & ns \\
\hline Percentage of total resin in peat & ns & ns & ns & ns & ns & ns & ns & 0.57 & ns \\
\hline Percentage of resin $C$ in total bitumen & ns & 0.76 & ns & ns & 0.31 & ns & 0.28 & ns & 0.17 \\
\hline Percentage of cellulose $C$ in peat & ns & ns & ns & ns & ns & ns & ns & ns & 0.67 \\
\hline $3400 / 2920$ intensity IR intensity ratio & ns & ns & ns & ns & ns & -0.53 & ns & ns & ns \\
\hline \multicolumn{10}{|l|}{ Humic acid properties } \\
\hline$\%$ Hymatomelanic acid in humic acid & ns & ns & ns & ns & ns & 0.16 & ns & ns & ns \\
\hline $3400 / 2920$ IR intensity ratio & ns & -0.17 & ns & ns & ns & ns & ns & ns & ns \\
\hline $1720 / 2920$ IR intensity ratio & ns & ns & ns & ns & -0.45 & ns & ns & ns & -0.23 \\
\hline \multicolumn{10}{|l|}{ Fulvic acid properties } \\
\hline $\mathrm{H} / \mathrm{C}$ atomic ratio & 0.23 & ns & ns & ns & ns & ns & ns & ns & ns \\
\hline $3400 / 2920$ IR intensity ratio & ns & ns & ns & -0.66 & ns & ns & -0.58 & -0.44 & ns \\
\hline$p$-value & 0.007 & 0.004 & 0.001 & 0.006 & 0.007 & 0.023 & 0.010 & 0.001 & 0.005 \\
\hline
\end{tabular}

${ }^{\text {a }}$ Stepwise regression with backward automatic variable selection; $\mathrm{ns}=$ non-significant $(p>0.05)$. 


\subsection{Simple Regressions}

\subsubsection{Peat-Herbicide System}

In the peat-herbicide system the characteristics related to the retention process of the three herbicides suggested some common interactions (Table 5). As expected, the sorption extent showed significant positive correlations with the amount of oxidizable $C$, and a negative correlation with the ash content. Another set of parameters suggested that specific peat characteristics could be favorable for the retention of compounds of low solubility into water. This is the case of negative correlations with the IR $3400 / 2920 \mathrm{~cm}^{-1}(\mathrm{OH}$ stretching/alkyl) ratio in the HA and FA, and the $1720 / 2920 \mathrm{~cm}^{-1}$ (carboxyl/alkyl) ratio in HA.

The subfractions isolated by preparative chromatography from the total bitumen fraction were found to be a source of useful descriptors. The sorption capacity was higher in peats with high amounts of resins (the latter in general consist of high-molecular weight colored, lignin or humic-like substances), whereas negative correlations were found with the wax fraction.

Some correlations were only significant $(p<0.05)$ in the case of alachlor and atrazine, whose sorption was negatively correlated with the amount of HA, and positively with the amounts of bitumen and of its polar macromolecular humic-like fraction remaining in the chromatographic column.

The particle size distribution of peat fibers does not appear to be of great value as an indicator of herbicide sorption, although it is used as a classical indicator of the degree of transformation of the peat. Nevertheless, the most significant correlations with peat maturity occurred in the case of the sorption of alachlor, which was also related with the hemicellulose content, suggesting that the sorption improves in the case of the less decomposed peats.

\subsubsection{Herbicide-Peat-Soil System}

When examining the interaction in the peat-soil system, the variables most significantly correlated with the intensity of the sorption were basically the same, but their relative importance (in terms of the level of significance) varied greatly (Table 5). For instance, there was no significant influence of variables such as ash content, or variables related to the extent of the aliphatic moiety in the peat humic fractions $(\mathrm{H} / \mathrm{C}$ atomic ratio and $3400 / 2920 \mathrm{~cm}^{-1}$ IR band ratio of the FA) or the amount of the acidic bitumen subfraction.

Other independent variables remained highly informative of the potential of the peat to retain plaguicides even after interaction with soil components. This was the case with the resin fraction, correlated with the retention of hydrophobic molecules. In addition, the sorption in soil of atrazine and linuron was found to significatively increase after the addition of peats with high concentration of free hydrocarbons, and decreased with peats showing a high $3400 / 2920 \mathrm{~cm}^{-1}$ IR intensity ratio.

\subsection{Multiple Regression Models}

Backward automatic variable selection was used to remove from the model the variables with minor contribution to the total inertia of the system (Table 6). The original data matrix was previously normalized (mean $=0$, standard deviation $=1$ ) to obtain multiple regression functions with the extent of the coefficients proportional to the importance of each variable, regardless of the units of the original data.

The standardized coefficients of the multiple regression functions confirmed some of the previous findings on factors related to sorption of herbicides in peat and peat-soil systems and provided additional information.

\subsubsection{Herbicide-Peat System}

The sorption values of the three herbicides studied suggest the significant role of hydrophobic fractions (i.e., total bitumen in atrazine, resins in linuron, or low concentration of total wax in alachlor) and the characteristics of the humic substances indicative of the importance of the aliphatic backbone with respect to hydrophilic groups (negative coefficients 
for the $3400 / 2920 \mathrm{~cm}^{-1}$ IR band ratio in the FA spectra in the case of atrazine and linuron), or positive coefficient of the $\mathrm{H} / \mathrm{C}$ atomic ratio of the FA fraction in the case of alachlor.

\subsubsection{Herbicide-Peat-Soil System}

The significant coefficients $(p<0.05)$ of the functions (Table 6) calculated for the herbicide-peat-soil system suggested, as in the case of the simple regressions, a weak influence of the of organic $C$, whereas the importance of resins became apparent.

\subsubsection{Changes in the Peat Reactivity after its Interaction with Soil}

Finally, the coefficients calculated from the data matrix with the percentage enhancement calculated after subtracting the sorption in peat alone from the sorption in the peat-soil mixture showed a modified behavior with differences in terms of herbicide type (Table 6). In the case of alachlor, the coefficients of the peat in soil system suggested that the increase in sorption is associated with the bitumen content and a low oxidation, and in the case of atrazine with a low 1720/2920 IR intensity ratio and a high content in the less polar HA fraction (hymatomelanic acid). In the case of linuron, the coefficients also suggest the importance of the hydrophobicity of the HA (IR ratio) and of the high concentration of resin and cellulose, i.e., surrogates for a low or intermediate degree of humification.

\section{Discussion}

No single factor appears to play a dominant role in explaining the above results. A general observation was that the highest sorption values were obtained in systems with the comparatively least decomposed organic matter, characterized by the dominance of fibers consisting of plant tissues, or by a low degree of association between humic substances and the mineral fraction.

The presence of non-decomposed biomass constituents could be involved in effective diffusion phenomena with a role in retention of compounds of low molecular weight. It is remarkable that the sorption values of herbicides were substantially different when studied on isolated organic matter and when studied on organic matter applied to the soil. In some cases, sorption was lower than the sum of the sorption in both materials separately, whereas in other cases a significant increase was observed.

The fact that the sorption values in peat-soil systems were different from those in the two materials separately is indicative of new emergent properties. The decrease in sorption values in the organo-mineral system could be explained by the fact that active sites in organic matter were also used to form bonds with the soil, so they were no longer available to interact with the herbicide. Although the cases in which a synergistic effect occurred, i.e., a greater sorption than expected from the sum of the sorption in the soil and in the peat, would not necessarily indicate few links between the organic matter and the mineral, changes in the soil microstructure at the level of the soil matrix may occur, such as new microsites where the diffusion of small molecules is possible. In addition, changes in the hydrophobicity of the soil matrix (such as oxygen-containing functional groups of the peat being blocked by cationic bonding with soil minerals) were also likely to occur, which would make soil surfaces more suitable for herbicide retention. In fact, the formation of $\mathrm{H}$-bonds and similar interactions within the soil-peat system would decrease the total solvated surface both of peat and in the soil, increasing the hydrophobic character of the whole soil matrix and favoring the effective retention of compounds with low solubility in water [57].

The importance of the hydrophobic components of the organic material observed in the case of alachlor and atrazine indicates that, for these herbicides, some minor amphiphilic fractions conferring high activity to soil reactive surfaces could be very significant in forecasting the sorption performance.

Concerning peat maturity, the fact that the greatest sorption enhancement was observed in the most fibric material (Neuhaus) could point to a positive role of flexibility in the skeletal constituents of peat, which could favor structural rearrangements together with the soil clay minerals, thus leading to differentiation of active microcompartments. In other 
peats in advanced humification stages (Padul) or high calcium concentration (Daimiel), the less significant enhancement effect of the organo-mineral interactions could be due to the comparatively rigid organic structures due to internal cross-linking and/or to effective bridging through bivalent ions.

The above suggestions agree with the results of the simple linear regression models in which the negative correlations between peat bulk density and herbicide sorption could, at first sight, support the above suggested substantial performance of the herbicide interactions with low rigidity materials containing high proportion of non-decomposed plant tissues. Nevertheless, a greater number of more conspicuous interactions were found with the actual density, suggesting that peat densities also behaved as indirect indicators of the carbon and ash content.

The large number of significant simple correlations reinforces the idea that the herbicide sorption is a complex process depending on the interaction between certain sets of variables, more than on the chief influence of one only parameter. In consequence, a more accurate description of the whole sorption process could be obtained by multiple regression models. In general, the models for the three herbicides studied in the herbicide-peat system tend to emphasize the importance of factors such as the amount of specific minor extractive fractions (total bitumen in atrazine, resins in linuron, or low concentration of total wax in alachlor) and some characteristics of the humic substances in general suggesting higher connection between the retention process and the aliphatic backbone than of the oxygen-containing functional groups (negative coefficients for the $3400 / 2920 \mathrm{~cm}^{-1}$ IR band ratio in the FA spectra in the case of atrazine and linuron). The positive coefficient of the atomic $\mathrm{H} / \mathrm{C}$ ratio of the FA fraction in the case of alachlor is also supportive of the above suggestion.

These mechanisms would also be valid to justify the differences in the behavior of organic matter after its incorporation into the soil. For instance, in the case of alachlor, the coefficients of the peat in soil suggested a positive effect caused by a relatively low decomposition degree, which is associated with the high bitumen content and a low oxidation degree. This coincides in interpretation, but with different variables, with the behavior observed in the peat alone. In the case of atrazine, the most significant coefficients suggested the importance of a low content of H-bonded oxygen-containing groups in the HA with respect to its aliphatic backbone. The proportion of organic subfractions with an intermediate polarity (hymatomelanic and wax acid fractions) was also included in the models. In the case of linuron, the coefficients also point to the relevance of a low hydrophilic character in the HAs (IR ratios) and high resin and cellulose concentration, which are associated with low-to medium decomposition degree of the organic matter. The above results are in agreement with previous works on atrazine and HAs [58], which showed that the affinity of the herbicide to the solid surface depends on the nature of both, with each component strongly affecting the mobility of the other. In particular, differences in sorption in terms of interactions between HAs and minerals described in previous studies on atrazine [59] suggested a large influence, mainly due to chemical bonding between the $\mathrm{OH}$ groups on the surface of the amorphous hydrated oxides. This is also consistent with the behavior of atrazine in systems including isolated soil fractions such as particulate organic matter and HAs, suggesting that a fraction of the sorption sites in soil aggregates was not accessed [60].

The above considerations were summarized in the correspondence analysis, performed to present a comprehensive description of the sorption system where peat characteristics play a somewhat different bearing depending on the herbicide under study, and this pattern also shows differences depending on the interaction with soil constituents (Figure 2). Although parameters indicating low diagenetic transformation (e.g., bitumen content, carbohydrate and lignin, low-density fibers) were predominantly involved in the peat system, in the case of the soil-peat system, the sorption was mainly associated with parameters related to peat colloidal properties (such as the concentration and base saturation of oxygen-containing functional groups in HAs, i.e., 1720/2920 intensity ratio in the IR spectra and $\mathrm{O} / \mathrm{C}$ atomic ratio). 


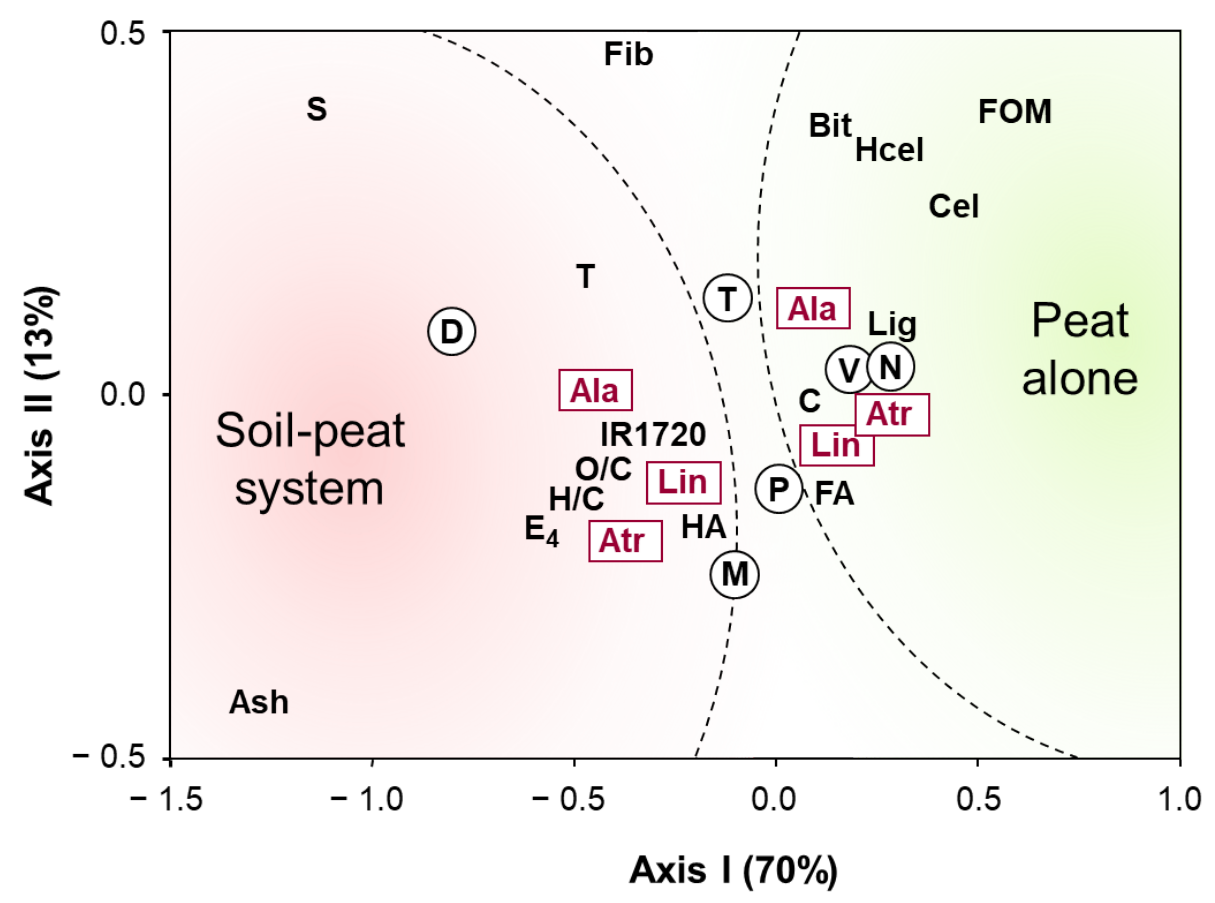

Figure 2. Correspondence analysis showing the influence of several analytical characteristics of peats on the herbicide sorption (labels in boxes) in two different systems: peat alone and peat-treated soil. Encircled labels correspond to peat samples: D = Daimiel; $M=$ Mazagón; $\mathrm{N}=$ Neuhaus; $\mathrm{P}=$ Padul; $\mathrm{T}=$ Torreblanca; $\mathrm{V}=$ Vivero. Variables corresponding to herbicide sorption are indicated in squared boxes: Ala $=$ alachlor; Atr $=$ atrazine; Lin $=$ linuron. Bold labels represent other

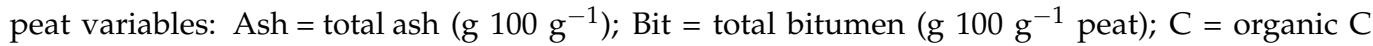
$\left(\mathrm{g} 100 \mathrm{~g}^{-1}\right)$; Cel = cellulose ( $\mathrm{g} 100 \mathrm{~g}^{-1}$ peat); $\mathrm{E} 4=$ optical density at $465 \mathrm{~nm}$ in humic acid (AU);

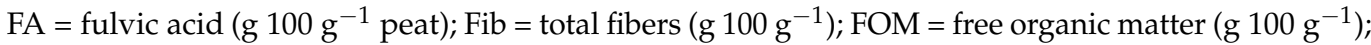
$\mathrm{H} / \mathrm{C}=\mathrm{H} / \mathrm{C}$ atomic ratio in humic acid; $\mathrm{HA}=$ humic acid $\left(\mathrm{g} 100 \mathrm{~g}^{-1}\right.$ peat $)$; Hcel = hemicellulose ( $\mathrm{g} 100 \mathrm{~g}^{-1}$ peat); IR1720 $=1720 / 2920 \mathrm{~cm}^{-1}$ intensity ratio in the IR spectra from humic acid;

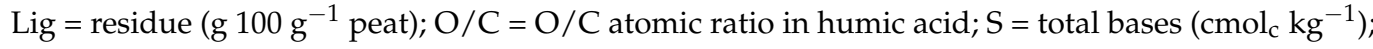
$\mathrm{T}=$ Total exchange capacity $\left(\mathrm{cmol}_{\mathrm{C}} \mathrm{kg}^{-1}\right)$. The percentage of the total variance accounted for by the two first components is shown in the axes.

\section{Conclusions}

The different sorption values of herbicides observed for various types of organic matter and for the same materials applied to a soil with a very low carbon content clearly indicate that when the organic amendment interacts with the mineral components of the soil, the sorption of herbicides is modified qualitatively and quantitatively. The differences found between the herbicide-organic matter system and the herbicide-soil-organic matter system may be due both to blocking of the reactive functional groups of organic matter (after establishing links with the mineral soil matrix), and to the development of emergent properties, presumably due to changes in the microstructure and reactivity of the soil organic matrix. These changes would influence both the accessibility of the herbicide to the hydrophobic surfaces of the organo-mineral complex of the soil, in addition to the reactivity of functional groups of organic matter and clay minerals that regulate the sorption mechanisms of compounds with low solubility in water.

Author Contributions: Conceptualization, G.A.; methodology, J.D. and G.A.; formal analysis, J.D. and G.A.; investigation, J.D. and G.A.; resources, G.A.; writing—original draft preparation, G.A.; writingreview and editing, J.D. and G.A.; supervision, G.A.; project administration, G.A.; funding acquisition, J.D. and G.A. All authors have read and agreed to the published version of the manuscript. 
Funding: This research was funded by the Spanish Agencia Estatal de Investigación (AEI) and the European Regional Development Fund (ERDF), through the Project AGL2017-83325-C4-1-R.

Institutional Review Board Statement: Not applicable.

Informed Consent Statement: Not applicable.

Data Availability Statement: The data presented in this study are openly available in references number [41-45].

Conflicts of Interest: The authors declare no conflict of interest.

\section{References}

1. Bartha, R. Pesticide residues in humus. ASM News 1980, 46, 356-360.

2. Koskinen, W.C.; Harper, S.S. The Retention Process: Mechanisms. In Pesticides in the Soil Environment: Processes Impacts and Modelling; Chapter 3, SSSA Book Series, no. 2; Cheng, H.H., Ed.; Soil Science Society of America: Madison, WI, USA, 1990; pp. 51-76.

3. Gerke, J. Concepts and misconceptions of humic substances as the stable part of soil organic matter: A review. Agronomy 2018, 8, 76. [CrossRef]

4. Jindo, K.; Canellas, L.P.; Albacete, A.; Dos Santos, L.F.; Frinhani Rocha, R.L.; Baia, D.C.; Aguiar Canellas, N.O.; Goron, T.L.; Olivares, F.L. Interaction between humic substances and plant hormones for phosphorous acquisition. Agronomy 2020, 10, 640. [CrossRef]

5. Chowdhury, I.F.; Doran, G.S.; Stodart, B.J.; Chen, C.; Wu, H. Trifluralin and atrazine sensitivity to selected cereal and legume crops. Agronomy 2020, 10, 587. [CrossRef]

6. Mudhoo, A.; Garg, V.K. Sorption, transport and transformation of atrazine in soils, minerals and composts: A review. Pedosphere 2011, 21, 11-25. [CrossRef]

7. Novotny, E.H.; Turetta, A.P.D.; Resende, M.F.; Rebello, C.M. The quality of soil organic matter, accessed by ${ }^{13} \mathrm{C}$ solid state nuclear magnetic resonance, is just as important as its content concerning pesticide sorption. Environ. Pollut. 2020, 266, 115298. [CrossRef]

8. Senesi, N.; Testini, C. The Environment Fate of Herbicides: The Role of Humic Substances, in R. Hallberg: Environmental Biogeochemistry. Ecol. Bull. 1983, 35, 477-490.

9. Chang, C.-Y.; Zheng, Y.-T.; Lü, Y.-Z. Adsorption characteristics and mechanism of atrazine on three types of humic acid. Guang Pu Xue Yu Guang Pu Fen Xi/Spectrosc. Spectr. Anal. 2010, 30, 2641-2645. [CrossRef]

10. Tsui, L.; Roy, W.R. The potential applications of using compost chars for removing the hydrophobic herbicide atrazine from solution. Bioresour. Technol. 2008, 99, 5673-5678. [CrossRef]

11. Zhu, L.-J.; Zhao, Y.; Chen, Y.-N.; Cui, H.-Y.; Wei, Y.-Q.; Liu, H.-L.; Chen, X.-M.; Wei, Z.-M. Characterization of atrazine binding to dissolved organic matter of soil under different types of land use. Ecotoxicol. Environ. Saf. 2018, 147, 1065-1072. [CrossRef] [PubMed]

12. Wu, Q.; Yang, Q.; Zhou, W.; Zhu, L. Sorption characteristics and contribution of organic matter fractions for atrazine in soil. J. Soils Sediments 2015, 15, 2210-2219. [CrossRef]

13. Dorado, J.; Almendros, G. Assessment of molecular descriptors involved in the sorptive interactions of phenoxy-carboxylic herbicides in soil treated with different concentrations of humic acid. Toxicol. Environ. Chem. 2001, 84, 21-32. [CrossRef]

14. Dorado, J.; López-Fando, C.; Zancada, M.-C.; Almendros, G. Sorption-desorption of alachlor and linuron in a semiarid soil as influenced by organic matter properties after 16 years of periodic inputs. J. Agric. Food Chem. 2005, 53, 5359-5365. [CrossRef] [PubMed]

15. Azzouzi, E.E.L.; Fekhaoui, M. Disposal of pesticides into the environment by adsorption: Case of atrazine. Res. J. Pharm. Biol. Chem. Sci. 2016, 7, 2590-2596.

16. Almendros, G. Sorptive interactions of pesticides in soils treated with modified humic acids. Eur. J. Soil Sci. 1995, 46, 287-301. [CrossRef]

17. Kunlanit, B.; Butnan, S.; Vityakon, P. Land-use changes influencing C sequestration and quality in topsoil and subsoil. Agronomy 2019, 9, 520. [CrossRef]

18. Almendros, G.; Dorado, J. Molecular characteristics related to the biodegradability of humic acid preparations. Eur. J. Soil Sci. 1999, 50, 227-236. [CrossRef]

19. Jindo, K.; Sánchez-Monedero, M.A.; Matsumoto, K.; Sonoki, T. The efficiency of a low dose of biochar in enhancing the aromaticity of humic-like substance extracted from poultry manure compost. Agronomy 2019, 9, 248. [CrossRef]

20. Stipičević, S.; Fingler, S.; Drevenkar, V. Effect of organic and mineral soil fractions on sorption behaviour of chlorophenol and triazine micropollutants. Arh. Hig. Rada. Toksikol. 2009, 60, 43-52. [CrossRef]

21. Rodríguez-Cruz, M.S.; Valderrábano, M.; Del Hoyo, C.; Sánchez-Martín, M.J. Physicochemical study of the sorption of pesticides by wood components. J. Environ. Qual. 2009, 38, 719-728. [CrossRef]

22. Plakas, K.V.; Karabelas, A.J. A systematic study on triazine retention by fouled with humic substances NF/ULPRO membranes. Sep. Purif. Technol. 2011, 802, 246-261. [CrossRef] 
23. Radwan, E.K.; Abdel Ghafar, H.H.; Moursy, A.S.; Langford, C.H.; Bedair, A.H.; Achari, G. Adsorptive removal of hazardous organic water pollutants by humic acid-carbon hybrid materials: Kinetics and isotherm study. Desalin. Water Treat. 2017, 80, 297-305. [CrossRef]

24. Chokejaroenrat, C.; Watcharenwong, A.; Sakulthaew, C.; Rittirat, A. Immobilization of atrazine using oxidized lignite amendments in agricultural soils. Water Air Soil Pollut. 2020, 231, 249. [CrossRef]

25. Wang, B.; Zhang, W.; Li, H.; Fu, H.; Qu, X.; Zhu, D. Micropore clogging by leachable pyrogenic organic carbon: A new perspective on sorption irreversibility and kinetics of hydrophobic organic contaminants to black carbon. Environ. Pollut. 2017, 220, 1349-1358. [CrossRef]

26. Mendes, K.F.; Hall, K.E.; Spokas, K.A.; Koskinen, W.C.; Tornisielo, V.L. Evaluating agricultural management effects on alachlor availability: Tillage, green manure, and biochar. Agronomy 2017, 7, 64. [CrossRef]

27. Kulikova, N.A.; Perminova, I.V. Sorption-desorption of atrazine on mineral-bound humic substances related to their structure. Fresenius Environ. Bull. 2007, 16, 1061-1068.

28. Dutta, A.; Mandal, A.; Manna, S.; Singh, S.B.; Berns, A.E.; Singh, N. Effect of organic carbon chemistry on sorption of atrazine and metsulfuron-methyl as determined by ${ }^{13}$ C-NMR and IR spectroscopy. Environ. Monit. Assess. 2015, 187, 1-12. [CrossRef] [PubMed]

29. Erny, G.L.; Gonçalves, B.M.; Esteves, V.I. Immobilized humic substances and immobilized aggregates of humic substances as sorbent for solid phase extraction. J. Chromatogr. A 2013, 1306, 104-108. [CrossRef]

30. Besse-Hoggan, P.; Alekseeva, T.; Sancelme, M.; Delort, A.-M.; Forano, C. Trazine biodegradation modulated by clays and clay/humic acid complexes. Environ. Pollut. 2009, 157, 2837-2844. [CrossRef] [PubMed]

31. D'Orazio, V.; Miano, T. Fluorescence properties of humic acid interaction products with s-triazine and bipyridilium herbicides and their Cu complexes: A multivariate approach. J. Soils Sediments 2018, 18, 1347-1354. [CrossRef]

32. Hong, R.; Zhang, L.; Zhu, W.; Gu, C. Photo-transformation of atrazine in aqueous solution in the presence of $\mathrm{Fe}^{3+}$-montmorillonite clay and humic substances. Sci. Total Environ. 2019, 652, 224-233. [CrossRef]

33. Prado, B.; Duwig, C.; Hidalgo, C.; Müller, K.; Mora, L.; Raymundo, E.; Etchevers, J.D. Transport, sorption and degradation of atrazine in two clay soils from Mexico: Andosol and Vertisol. Geoderma 2014, 232, 628-639. [CrossRef]

34. González-Márquez, L.C.; Hansen, A.M.; González-Farias, F.A. Effect of mono and divalent salts on the conformation and composition of a humic acid and on atrazine adsorption. Environ Sci. Pollut. Res. 2018, 25, 17509-17518. [CrossRef] [PubMed]

35. Wershaw, R.L.; Burcar, P.J.; Goldberg, M.C. Interaction of pesticides with natural organic material. Environ. Sci. Technol. 1969, 3 , 271-273. [CrossRef]

36. Sims, G.K.; Radosevich, M.; He, X.T.; Traina, S.J. The Effects of Sorption on the Bioavailability of Pesticides. In Biodegradation. Natural and Synthetic Materials; Betts, W.B., Ed.; Springer: New York, NY, USA, 1991; pp. 119-137.

37. Hesketh, N.; Jones, M.N.; Tipping, E. The interaction of some pesticides and herbicides with humic substances. Anal. Chim. Acta 1996, 327, 191-201. [CrossRef]

38. Morita, H. Linuron adsorption and the degree of decomposition of peats as measured by rubbed fibre content and pyrophosphate index. Can. J. Soil Sci. 1976, 56, 105-109. [CrossRef]

39. Singh, R.; Gerritse, R.G.; Aylmore, L.A.G. Adsorption-desorption behaviour of selected pesticides in some Western Australian soils. Aust. J. Soil Res. 1989, 28, 227-243. [CrossRef]

40. Dorado, J.; González-Vila, F.J.; Zancada, M.C.; Almendros, G.; López-Fando, C. Pyrolytic descriptors responsive to changes in humic acid characteristics after long-term sustainable management in dryland farming system in Central Spain. J. Anal. Appl. Pyrolysis 2003, 68/69, 299-314. [CrossRef]

41. Almendros, G. Composición y Propiedades de la Materia Orgánica en las Principales Turberas Españolas. Ph.D. Thesis, Complutense University of Madrid, Madrid, Spain, 1981. Available online: https:/ / eprints.ucm.es/id/eprint/52481/1/53098560 78.pdf (accessed on 27 April 2021).

42. Almendros, G.; Dorado, E.; Polo, A. Contribución al estudio analítico de la turbera de Padul (Granada). Anal. Edafol. Agrobiol. 1981, 40, 163-178.

43. Almendros, G.; Polo, A.; Dorado, E. Características de la materia orgánica en las formaciones turbosas litorales de Torreblanca (Castellón). Anal. Edafol. Agrobiol. 1981, 40, 223-235.

44. Almendros, G.; Polo, A.; Dorado, E. Fraccionamiento y caracterización de la materia orgánica de la turbera de Mazagón. An. INIA Ser. Agric. 1982, 18, $29-42$.

45. Almendros, G.; Polo, A.; Dorado, E. Composición y propiedades de la materia orgánica de las formaciones turbosas eutróficas de la zona de los Ojos del Guadiana. Bol. Real Soc. Esp. Hist. Nat. Biol. 1982, 80, 23-35.

46. Walkley, A.; Black, A. An examination of the Degtjareff method for determining soil organic matter and a proposed modification of the chromic acid titration method. Soil Sci. 1934, 37, 29-38. [CrossRef]

47. Mehlich, A. Determination of cation- and anion-exchange properties of soils. Soil Sci. 1948, 66, 429-445. [CrossRef]

48. Dabin, B. Etude d'une méthode d'extraction de la matière humique du sol. Sci. Sol. 1971, 1, 47-63.

49. Duchaufour, P.H.; Jacquin, F. Comparaison des procesus d'humification dans les principaux types d'humus forestiers. Bull. AFES. 1975, 1, 29-36.

50. Dorado, E.; Polo, A. Fraccionamiento de ácidos fúlvicos. Anal. Edafol. Agrobiol. 1976, 35, 723-732. 
51. Varnero, M.T.; Schaefer, R. Étude écologique de la degradation et de 1'humification de feuilles de hetre (Fagus sylvatica). Effet des conditions de l'incubation (oxybiose et anoxybiose) sur le bilan chimique. In Biodegradation et Humification; Kilbertus, G., Ed.; Laboratoire de Botanique et de Microbiologie: Nancy, France, 1975; pp. 340-361.

52. Brink, R.H.; Dubach, P.; Lynch, D.L. Measurement of carbohydrates in soil hydrolyzates with anthrone. Soil Sci. 1960, 89, 157-166. [CrossRef]

53. Kononova, M.M. Soil Organic Matter: Its Nature, Its Role in Soil Formation and in Soil Fertility; Oxford: Pergamon, UK, 1966.

54. Ekman, E. A Chromatographic analysis of the wax components of peat and peat-forming plants. In International Workshop on Properties of Organic Peat Components and Their Effect on Metabolism; International Peat Society, Ed.; FAL: Braunschweig, Germany, 1977; pp. 1-22.

55. Dorado, J.; Tinoco, P.; Almendros, G. Soil parameters related with the sorption of 2,4-D and atrazine. Commun. Soil Sci. Plant Anal. 2003, 34, 1119-1133. [CrossRef]

56. Institut Technique des Céréales et des Fourrages STAT-ITCF. Manuel d'Utilisation; Institut Technique des Céréales et des Fourrages STAT-ITCF, Impressions Atelier: Paris, France, 1988.

57. Khan, S.U. Distribution and characteristics of bound residues of prometryn in an organic soil. J. Agric. Food Chem. 1982, 30, 175-179. [CrossRef]

58. Otalvaro, J.O.; Brigante, M. Interaction of pesticides with natural and synthetic solids. Evaluation in dynamic and equilibrium conditions. Environ. Sci. Pollut. Res. 2018, 25, 6707-6719. [CrossRef] [PubMed]

59. Huang, Y.; Liu, Z.; Li, Y.; Wei, L.; Yang, S. Effects of humic acids and minerals on adsorption-desorption of atrazine in soil. Acta Pedol. Sin. 2016, 53, 155-165. [CrossRef]

60. Yu, Z.; Sharma, S.; Huang, W. Differential roles of humic acid and particulate organic matter in the equilibrium sorption of atrazine by soils. Environ. Toxicol. Chem. 2006, 25, 1975-1983. [CrossRef] [PubMed] 